\title{
The combined impact of carbon type and catalyst-aided gasification process on the performance of a Direct Carbon Solid Oxide Fuel Cell
}

M. Konsolakis ${ }^{(a)}$, N. Kaklidis ${ }^{(b)}$, V. Kyriakou ${ }^{(c)}$, I. Garagounis $^{(c)}$, Tz. Kraia $^{(b, c)}$, A. Arenillas $^{(d)}$, J.A. Menéndez ${ }^{(d)}$, R. Strandbakke ${ }^{(e)}$, G.E. Marnellos $^{(b, c, f)}$

(a) School of Production Engineering and Management, Technical University of Crete, Greece

(b) Department of Mechanical Engineering, University of Western Macedonia, Greece

${ }^{(c)}$ Chemical Process \& Energy Resources Institute, CERTH, Greece

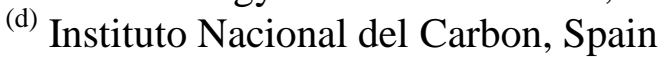

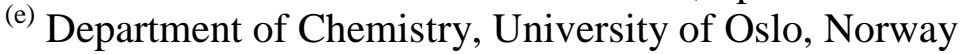

(f) Department of Environmental Engineering, University of Western Macedonia, Greece

To whom correspondence should be addressed

* Corresponding author.

E-mail: nkaklidis@uowm.gr (N. Kaklidis); Tel. +30 2461056701 


\begin{abstract}
The combined impact of carbon type (anthracite coal, bituminous coal and pine charcoal) and in situ, catalyst-aided, carbon gasification process on the electrochemical performance of a Direct Carbon Fuel Cell (DCFC) is explored. The effect of operation temperature $\left(700-800{ }^{\circ} \mathrm{C}\right)$ and catalyst $\left(\mathrm{Co} / \mathrm{CeO}_{2}\right)$ infusion to carbon feedstock under $\mathrm{CO}_{2}$ atmosphere at the anode chamber is systematically investigated in a cell of the type: Carbon $+\mathrm{CO}_{2}\left|\mathrm{Cu}-\mathrm{CeO}_{2} / \mathrm{YSZ} / \mathrm{Ag}\right| \mathrm{Air}$. All fuel samples were characterized, in terms of chemical composition, crystallite structure (XRD), pore structure (BET), surface morphology (SEM), particle size distribution (PSD) and thermogravimetric analysis (TGA), in order to obtain a close relationship between the carbon characteristics and the DCFC performance. The results reveal that in the absence of catalyst, the optimum performance is obtained for the charcoal sample $\left(\mathrm{P}_{\max } \sim 12 \mathrm{~mW} / \mathrm{cm}^{2}\right)$, due to its high oxygen and volatile matter contents. Catalyst infusion to carbon feedstock results in a considerable increase in the achieved cell power density up to $225 \%$, depending on carbon type and temperature. The enhanced performance obtained by infusing $\mathrm{Co} / \mathrm{CeO}_{2}$ catalyst into carbon is ascribed to the pronounced effect of catalyst on in situ carbon gasification, through the reverse Boudouard reaction $\left(\mathrm{C}+\mathrm{CO}_{2} \rightarrow 2 \mathrm{CO}\right)$, and the subsequent faster diffusion and electro-oxidation of formed $\mathrm{CO}$ at the anodic three-phase boundary.
\end{abstract}

Keywords: Direct Carbon Fuel Cell; Internal catalytic gasification; $\mathrm{Co} / \mathrm{CeO}_{2}$ catalyst; Anthracite coal; Bituminous coal; pine charcoal 


\section{Introduction}

Coal is by far the most abundant, economic and widely distributed fossil resource, presently accounting for more than $30 \%$ of the global energy consumption [1]. Nowadays, carbon conversion to energy mainly takes place in conventional coal-fired plants, in which, however, several issues related to the thermodynamic limitations of conventional thermal cycles and the increased emissions per unit of produced energy, render this process insufficient for a sustainable future. Direct Carbon Fuel cells (DCFCs) can effectively exploit the chemical energy of solid carbonaceous fuels in an efficient and environmental friendly manner, where contrary to conventional power plants, the chemical energy of the carbonaceous feedstock can be directly converted to electricity, with a lower $\mathrm{CO}_{2}$ footprint [2-4]. Moreover, DCFCs have several advantages, compared to conventional power plants and gaseous fuelled Solid Oxide Fuels Cells (SOFCs), such as the high theoretical energy efficiency [2,5-7], the high energy density of carbon compared to liquid or gaseous fuels [8], the abundance and low price of coal $[4,9]$, the almost zero $\mathrm{NO}_{\mathrm{X}}$ effluents and the ease of handling the associated $\mathrm{CO}_{2}$ emissions [10], facilitating the coupling of a DCFC unit with $\mathrm{CO}_{2}$ capture and sequestration.

Up to date, various electrolytes, such as molten hydroxides, molten carbonates and solid oxides have been employed in DCFC applications. Among them, the solid oxide (e.g., YSZ as the solid electrolyte) DCFCs offer the well established advantages of SOFC technology. However, the limited interaction between solid carbon and solid electrode/electrolyte interphase hinders the delivery of carbon and its direct electro-oxidation at three-phase-boundary (TPB). Hence, research efforts have mainly been focused on molten hydroxide [8,11] or molten carbonate electrolytes $[12,13]$, to overcome the mass transfer restrictions. However, durability problems relating to the corrosive nature of these electrolytes have restricted the development of molten electrolyte fuel cells [12-14].

Lately several strategies have been explored to increase the electrochemical performance in DCFCs, including among others: the integration of a DCFC with an internal or external gasification process [15-19], and the modification [5,20,21] or activation [22-24] of the employed carbon fuels. For instance, Gür et al. [16] and C. Li et al. [17] have independently reported high power densities in a SOFC fueled with CO generated in a decoupled Boudouard gasifier. Y. Wu et al. [18] have reported improved power output in a carbon-fueled SOFC involving internal catalytic gasification of carbon by a $\mathrm{Fe}_{\mathrm{m}} \mathrm{O}_{\mathrm{n}}$-alkali metal ( $\mathrm{Li}, \mathrm{K}, \mathrm{Ca}$ ) catalyst. In a similar manner, the DCFC performance was notably enhanced by catalyst (Fe, $\mathrm{Ni}, \mathrm{Ag}$ ) incorporation in the carbon fuel $[15,19,25,26]$. In this context, it has been suggested that gaseous $\mathrm{CO}$ and $\mathrm{CO}_{2}$, formed during the internal gasification of carbon, can significantly contribute to power generation, since $\mathrm{CO}$ can be better diffused and electrooxidized at the anodic TPB, while the generated $\mathrm{CO}_{2}$ can undergo the reverse Boudouard reaction $\left(\mathrm{C}+\mathrm{CO}_{2} \rightarrow 2 \mathrm{CO}\right)$ resulting in further $\mathrm{CO}$ formation [4,27,28]. In specific, the following reaction scheme can be accounted for in DCFCs: 


\section{Cathode Side}

$\mathrm{O}_{2}+4 \mathrm{e}^{-} \rightarrow 2 \mathrm{O}^{2-}$

Anode Side

$$
\begin{aligned}
& \mathrm{C}+2 \mathrm{O}^{2-} \rightarrow \mathrm{CO}_{2}+4 \mathrm{e}^{-} \\
& \mathrm{C}+\mathrm{O}^{2-} \rightarrow \mathrm{CO}+2 \mathrm{e}^{-} \\
& \mathrm{CO}+\mathrm{O}^{2-} \rightarrow \mathrm{CO}_{2}+2 \mathrm{e}^{-}
\end{aligned}
$$

The $\mathrm{CO}_{2}$ formed at anode TPB [Eqs. (2) and (4)] or directly employed as carrier gas in anode can react with carbon toward $\mathrm{CO}$, through the reverse Boudouard reaction:

$\mathrm{C}+\mathrm{CO}_{2} \rightarrow 2 \mathrm{CO}$

which although a non-electrochemical reaction, it has a key role in the DCFC performance, since its gaseous product, $\mathrm{CO}$, can easily diffuse at the active electrochemical zone much more rapidly than the solid carbon, contributing to power generation via reaction (4). Hence, it has been proposed that the overall carbon fuel cell efficiency can be ascribed mainly to gas-TPB interactions, rather than to the limited carbon-TPB contact $[16,17]$. In this perspective, a linear correlation between the maximum power output and the $\mathrm{CO}$ formation rate was recently established [29].

Various types of carbonaceous materials have been tested as fuels under DCFC operation and it has been demonstrated that the electrochemical performance is strongly affected by their composition and physicochemical properties [12,29-34]. In view of this fact we recently investigated the impact of various carbons [29] and biochars [35] on the DCFC performance. The results revealed that fuel physicochemical characteristics, such as volatile matter, structure disorder and sulfur content, notably affect the DCFC performance [29,35].

In light of the above aspects, the present work aims at investigating the combined impact of carbon type and catalyst-aided gasification process on the DCFC performance. Three different carbon samples, i.e., anthracite coal, bituminous coal and pine charcoal, were employed as fuels in a DCFC. The impact of internal catalytic gasification was assessed by utilizing a $\mathrm{Co} / \mathrm{CeO}_{2}$ catalyst as carbon additive and $\mathrm{CO}_{2}$ as carrier gas, towards promoting the rate of reverse Boudouard reaction. The results are interpreted based on the combined effect of catalyst addition and fuel properties on cell's electrochemical performance.

\section{Experimental}

\subsection{Materials preparation}

Carbon fuels. Three types of carbons with different composition and properties were employed as fuels. Specifically, two different coals were evaluated: a bituminous coal (BC) and an anthracite coal (AC), both from Spanish basins. These coals were selected in order to examine the influence of the coal maturation on carbon characteristics and consequently on DCFC performance. The third carbon was a pine charcoal (PCC), also from Spain. 
Catalysts. The wet impregnation method was used to prepare the $20 \mathrm{wt} . \% \mathrm{Co} / \mathrm{CeO}_{2}$ and 20 wt.\% $\mathrm{Cu} / \mathrm{CeO}_{2}$ samples, employed as feedstock additive and anode, respectively. $\mathrm{Ce}\left(\mathrm{NO}_{3}\right)_{3} \cdot 6 \mathrm{H}_{2} \mathrm{O}$ precursor $\left(99 \%\right.$, Sigma-Aldrich) was dissolved in distilled water and heated to $125^{\circ} \mathrm{C}$, under stirring, until all the water evaporated. The resulting sample was dried for $16 \mathrm{~h}$ at $110^{\circ} \mathrm{C}$, and then calcined for $2 \mathrm{~h}$ at $600^{\circ} \mathrm{C}$. Then, following identical steps, stoichiometric amounts of $\mathrm{Co}\left(\mathrm{NO}_{3}\right)_{2} \cdot 6 \mathrm{H}_{2} \mathrm{O}$ or $\mathrm{Cu}\left(\mathrm{NO}_{3}\right)_{2} \cdot 3 \mathrm{H}_{2} \mathrm{O}(99 \%$, Sigma-Aldrich) were dissolved in distilled water and impregnated onto the calcined $\mathrm{CeO}_{2}$ in order to yield a metal loading of $20 \mathrm{wt} . \%$ in both mixed oxide samples.

Carbon-catalyst feedstock. The impact of $\mathrm{Co} / \mathrm{CeO}_{2}$ catalyst on DCFC performance was examined by mixing $800 \mathrm{mg}$ of carbon with $400 \mathrm{mg}$ of catalyst. The carbon fuels were initially dissolved in $250 \mathrm{~cm}^{3}$ of $\mathrm{n}$-hexane, with sonication for $15 \mathrm{~min}$. Then the catalyst was added and the resulting solution was stirred on a heating plate at $70^{\circ} \mathrm{C}$ for $4 \mathrm{~h}$ until n-hexane was evaporated.

\subsection{Materials characterization}

Carbons were characterized, in terms of chemical composition, crystallite structure (XRD), pore structure (BET), surface morphology (SEM), particle size distribution (PSD) and thermogravimetric analysis (TGA). Prior to each characterization all samples were dry-milled in a bench mortar mill and sieved to under $75 \mu \mathrm{m}$.

Textural and morphological analysis. The textural characteristics of the samples were determined by $\mathrm{N}_{2}$ adsorption-desorption isotherms at $-196^{\circ} \mathrm{C}$ in the pressure range of $0-1$ bar in a Micromeritics Tristar 3020 apparatus. The morphology of the carbon fuels as well as of the carbon/catalyst mixtures was examined by scanning electron microscopy (SEM) using a Quanta FEG 650 microscope, equipped with an Apollo X detector for EDX measurements. The particle size distribution of the samples was determined by coulter analysis in Beckman Coulter LS 13320 Laser Diffraction Particle Size Analyzer with Aqueous Liquid Module (ALM).

Structural analysis. Diffractograms were recorded in a Bruker D8 powder diffractometer. It is equipped with a monochromatic $\mathrm{CuK}_{\alpha} \mathrm{X}$-ray source and an internal standard of Silicon powder, while the scanning rate used was $0.02^{\circ}$ per $2 \mathrm{~s}$, in the range of $5-90^{\circ}$.

Chemical analysis. All fuel samples were chemically characterized by means of elemental analysis (C, H, N, S and O wt\% content) in a LECO CHNS-932 (C, H, N, S) and LECO VTF-9000 (O) analyzers. Proximate analysis (volatile matter, ash and moisture content) was carried out using the LECO TGA-601 equipment. Ash composition was determined by X-ray fluorescence in a Bruker SRS 3000 device.

Thermogravimentric analysis. The reactivity of the samples was determined by means of thermogravimetric analysis in a Q5000 IR (TA Instruments) thermobalance. The weight loss profile was 
determined by increasing the temperature up to $1000^{\circ} \mathrm{C}$ at a rate of $10^{\circ} \mathrm{C} / \mathrm{min}$, under either inert (i.e., nitrogen) or reactive (i.e., $\mathrm{CO}_{2}$ ) atmosphere.

\subsection{DCFC fabrication and electrochemical testing}

The electrochemical cell used in the experiments has been described in detail elsewhere [29,35]. Briefly it consists of an yttria-stabilized zirconia (YSZ) tube $(15 \mathrm{~cm}$ length, I.D. $=16 \mathrm{~mm}, 1.5 \mathrm{~mm}$ thickness), closed flat at its bottom end. The cathode was deposited on the outside bottom wall of the YSZ tube, prepared from a Ag paste (05X Metallo-organic AG RESINATE) after calcination for $2 \mathrm{~h}$ at $850^{\circ} \mathrm{C}$ in air. The anode was prepared from a $\mathrm{Cu} / \mathrm{CeO}_{2}$ powder, mixed with ethylene glycol at a 1:2 weight ratio. This solution was heated to $200^{\circ} \mathrm{C}$ and stirred at $400 \mathrm{rpm}$ until half of the volume was evaporated. The resulting viscous suspension was then deposited on the inside bottom wall of the YSZ tube. The calcination procedure involved heating to $850^{\circ} \mathrm{C}$ for $2 \mathrm{~h}$ with a rate of $4^{\circ} \mathrm{C} / \mathrm{min}$, under static air. The cell was then cooled naturally to $200^{\circ} \mathrm{C}$, where the anode was reduced in a flow of $100 \% \mathrm{H}_{2}\left(30 \mathrm{~cm}^{3} / \mathrm{min}\right)$ for $2 \mathrm{~h}$. The weight of the anode deposited on the YSZ was equal to $115 \mathrm{mg}$, resulting in an apparent surface area of $1.7 \mathrm{~cm}^{2}$. Gold wires anchored on the electrodes surface served as current collectors, while for further improving the electrical contact at cathode, a thin Au film was applied upon the attached Au wire on the Ag electrode.

Fuel cell and AC impedance measurements were carried out in the temperature range of $700-800{ }^{\circ} \mathrm{C}$ under atmospheric pressure. In each experiment the fuel cell, loaded either with bare carbon or a carbon/catalyst mixture, was initially heated from room temperature to $700^{\circ} \mathrm{C}$ at a heating rate of 4 ${ }^{\circ} \mathrm{C} / \mathrm{min}$. A certified standard of $\mathrm{CO}_{2}(99.99 \%$ purity, Air Liquide) was employed as gasifying agent in the anode chamber, whereas the cathode was exposed to air. The gas flow, controlled by mass flowmeters (Tylan FM 360), was introduced into the cell at a total flowrate of $30 \mathrm{~cm}^{3}$ (STP)/min.

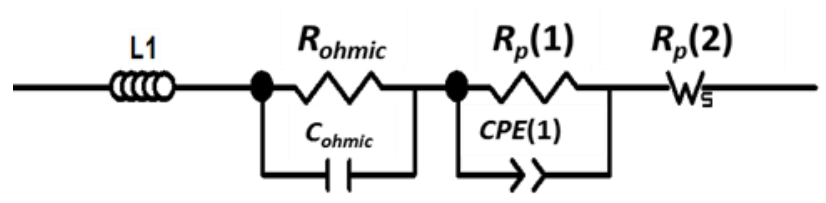

Figure 1. Equivalent circuit model, representing ohmic resistance $\left(R_{\text {ohmic }}\right)$ and capacitance $\left(C_{\text {ohmic }}\right)$, together with two parts of the polarization resistance, $R_{p}(1)$ and $R_{p}(2) . R_{p}(1)$ is dencovoluted in parallel with a constant phase element $\left(\mathrm{CPE}_{\mathrm{dl}}\right)$ representing double layer pseudo-capacitance, and $R_{p}(2)$ is represented by a Warburg element for mass transfer contribution.

The cell voltage and developed electrical current were monitored by means of digital multi-meters (RE69) and the external resistive load was controlled by a resistance box (Time Electronics 1051). The impedance spectra were obtained under open circuit conditions in a two electrodes set up and in 
the frequency range between $0.1 \mathrm{~Hz}$ and $1 \mathrm{MHz}$ with an amplitude of $30 \mathrm{mV}$ RMS, using the Versa Stat 4 electrochemical workstation by Princeton Applied Research. The impedance data was deconvoluted by using the Z-view software from Scribner Associates and by applying an equivalent circuit as presented in Fig. 1. The effluent from the anode chamber was analyzed by an on-line Gas Chromatograph (SRI 8610B) equipped with a Molecular Sieve 5A and Porapak Q columns.

\section{RESULTS AND DISCUSSION}

\subsection{Characterization studies of carbon fuels}

The physicochemical characteristics of carbon samples have been already studied in our previous work [29]. However, for discussion purposes, the main properties of carbon fuels are shortly presented again here, along with their particle size distribution, mineral matter composition, surface morphology and thermogravimetric analysis.

Textural \& morphological analysis. All samples exhibit a very low porosity, resulting in a BET area lower than $10 \mathrm{~m}^{2} / \mathrm{g}$. AC sample shows the lowest BET area $\left(3.0 \mathrm{~m}^{2} / \mathrm{g}\right)$ and available porosity $\left(0.01 \mathrm{~cm}^{3} / \mathrm{g}\right)$, whilst the PCC sample possesses the highest area $\left(11.0 \mathrm{~m}^{2} / \mathrm{g}\right)$ and pore volume $(0.05$ $\left.\mathrm{cm}^{3} / \mathrm{g}\right)$. BC presented intermediate values with BET area and porosity equal to $4.0 \mathrm{~m}^{2} / \mathrm{g}$ and 0.02 $\mathrm{cm}^{3} / \mathrm{g}$, respectively [35].

SEM pictures of carbon fuels are shown in Fig. 2. It can be clearly seen that the nature of the coals (Figs. 2a, 2b) is quite different from that of the pine charcoal (Fig. 2c), with the remaining plant structure still observable in the latter case. The different coal maturation between the BC and AC coals is difficult to be observed, which appear like similar carbonaceous materials. However, the presence of mineral matter can be distinguished as white spots in the micrographs, which are more abundant in the AC sample (Fig. 2a) as its mineral matter content is higher (see Table 2).
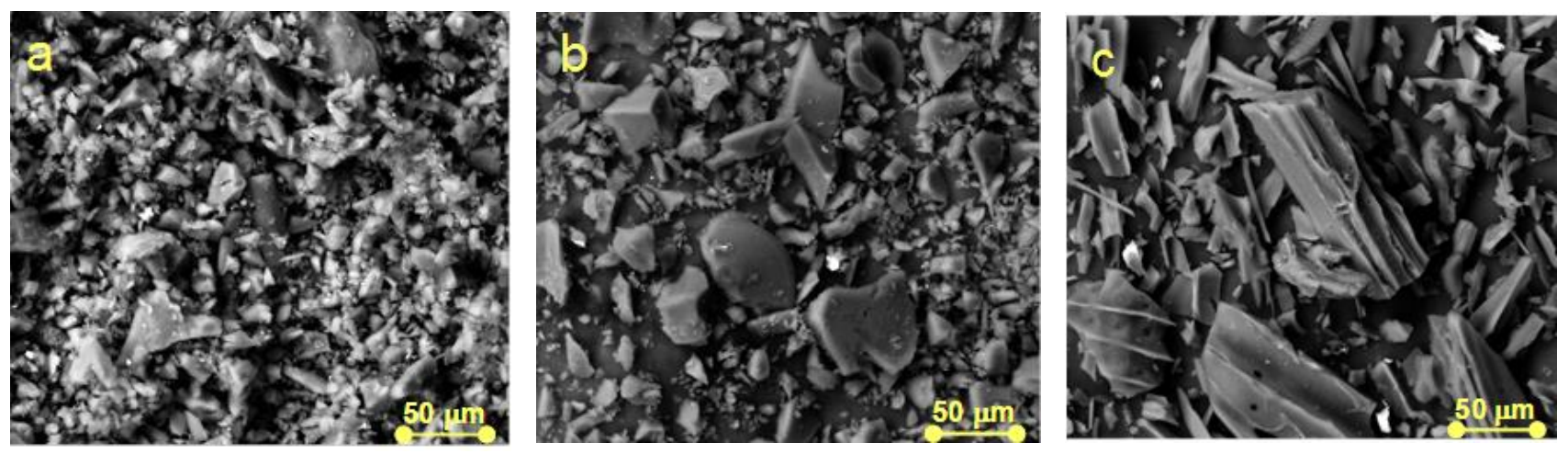

Figure 2. SEM micrographs of (a) anthracite coal, (b) bituminous coal and (c) pine charcoal.

The particle size distribution (PSD) was determined by coulter analysis (Fig. 3). It can be observed that the PSD profiles of the AC and BC samples are very similar, showing a maximum at ca. 35 
microns with a shoulder at ca. 15-17 microns. Particles are generally ranged between 2-50 microns. The particle size distribution of the PCC sample is wider, presenting a maximum also at ca. 35 microns but with a long tale at higher particle sizes (up to 110 microns).

Representative micrographs of carbon/catalyst mixture (800 mg coal + $400 \mathrm{mg}$ catalyst), when employing bituminous coal as fuel and $20 \mathrm{wt} . \% \mathrm{Co} / \mathrm{CeO}_{2}$ composite as catalyst are shown in Fig. 4. Gray spots correspond to catalyst particles while more dark areas to carbon particles, as revealed by EDS analysis (data not shown for brevity). Elemental mapping reveals a homogenous distribution of two counterparts. Carbon is mainly consisting of particles ranged from 2 to $50 \mu \mathrm{m}$, in accordance to coulter analysis (Fig. 3), which are decorated by catalyst particles of 1-2 $\mu \mathrm{m}$. The present results imply a sufficient contact between carbon and catalysts, which is expected to have a key role in the internal gasification process, and in consequence in DCFC performance (see below).

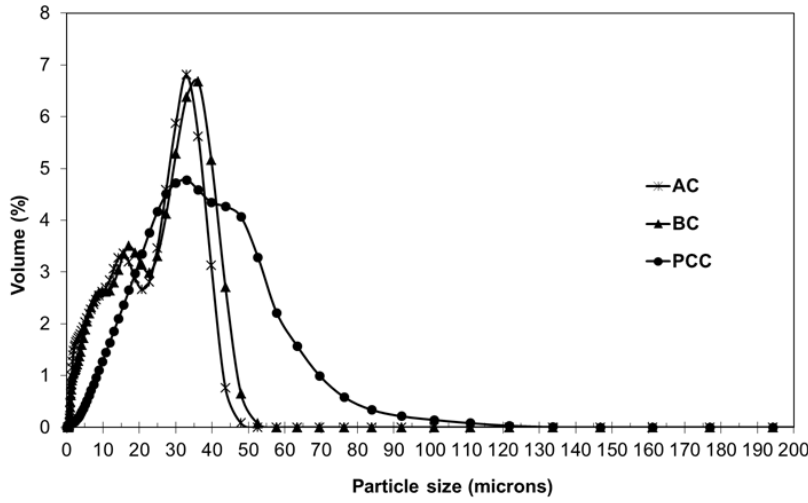

Figure 3. Particle size distribution of $\mathrm{AC}, \mathrm{BC}$, and PCC coals after dry milling.

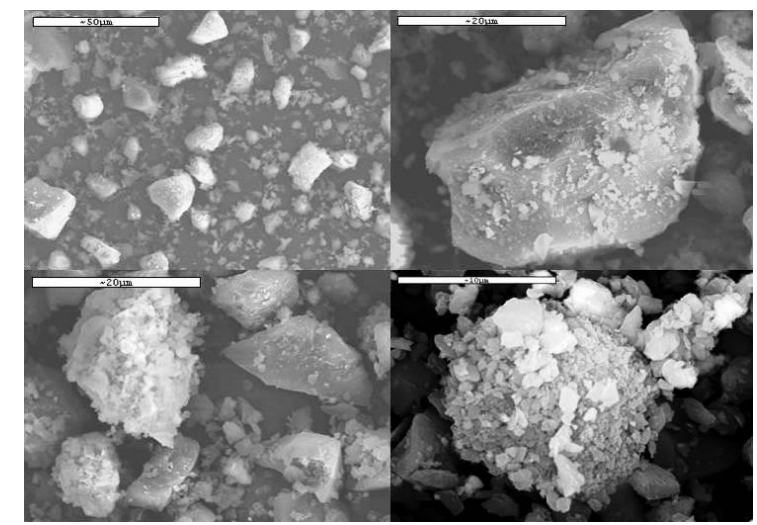

Figure 4. SEM micrographs of bituminous coal admixed with $\mathrm{Co} / \mathrm{CeO}_{2}$ catalysts.

Chemical analysis. In Table 2 the results of proximate and ultimate analysis of all carbon samples are shown. It is evident that the volatile matter content increases from AC to BC and PCC sample. The AC sample has the highest ash and sulphur contents, which could contribute to performance degradation. In contrast PCC has the highest volatile matter and oxygen contents, which are expected to contribute to a higher reactivity of this fuel and therefore to a higher carbon conversion and electrochemical performance.

Table 2. Proximate and ultimate analysis of the fuel samples

\begin{tabular}{|c|c|c|c|c|c|c|c|c|}
\hline \multirow[t]{2}{*}{ Coal } & \multicolumn{3}{|c|}{ Proximate Analysis (wt. \%) } & \multicolumn{5}{|c|}{ Ultimate Analysis (wt. \%, dry ash free basis) } \\
\hline & $\mathbf{V M}^{\mathbf{a}}$ & $\mathbf{A s h}^{\mathbf{a}}$ & Moisture & $\mathbf{C}$ & $\mathbf{H}$ & $\mathbf{N}$ & $\mathbf{S}$ & $\mathbf{O}$ \\
\hline $\mathbf{A C}$ & 9.7 & 32.5 & 1.5 & 88.6 & 4.0 & 1.5 & 2.2 & 3.7 \\
\hline BC & 18.5 & 4.6 & 1.0 & 91.9 & 4.7 & 1.5 & 0.9 & 1.0 \\
\hline PCC & 32.4 & 1.6 & 5.5 & 75.6 & 3.9 & 0.3 & 0.0 & 20.7 \\
\hline
\end{tabular}

${ }^{a}$ dry basis 
Structural analysis. Although the AC and BC coals present similar C, H, N and oxygen contents, the carbon structure is different in both samples as can be derived from the volatile matter content (i.e., 18.5 and $9.7 \mathrm{wt} \%$ for $\mathrm{BC}$ and $\mathrm{AC}$, respectively) and the reflectance parameter (i.e., 1.5 and $2.25 \%$ for $\mathrm{BC}$ and $\mathrm{AC}$, respectively ). This clearly indicates that $\mathrm{BC}$ presents a less developed structure due to the different coal maturity. Moreover, the PCC sample presents the broadest principal XRD peak (002) at ca. $25^{\circ}$ (Fig. 5), implying the least ordered carbonaceous structure among the samples studied. The increase of structure disorder from AC, to BC and finally to PCC, has been further verified by Raman spectroscopy [29].

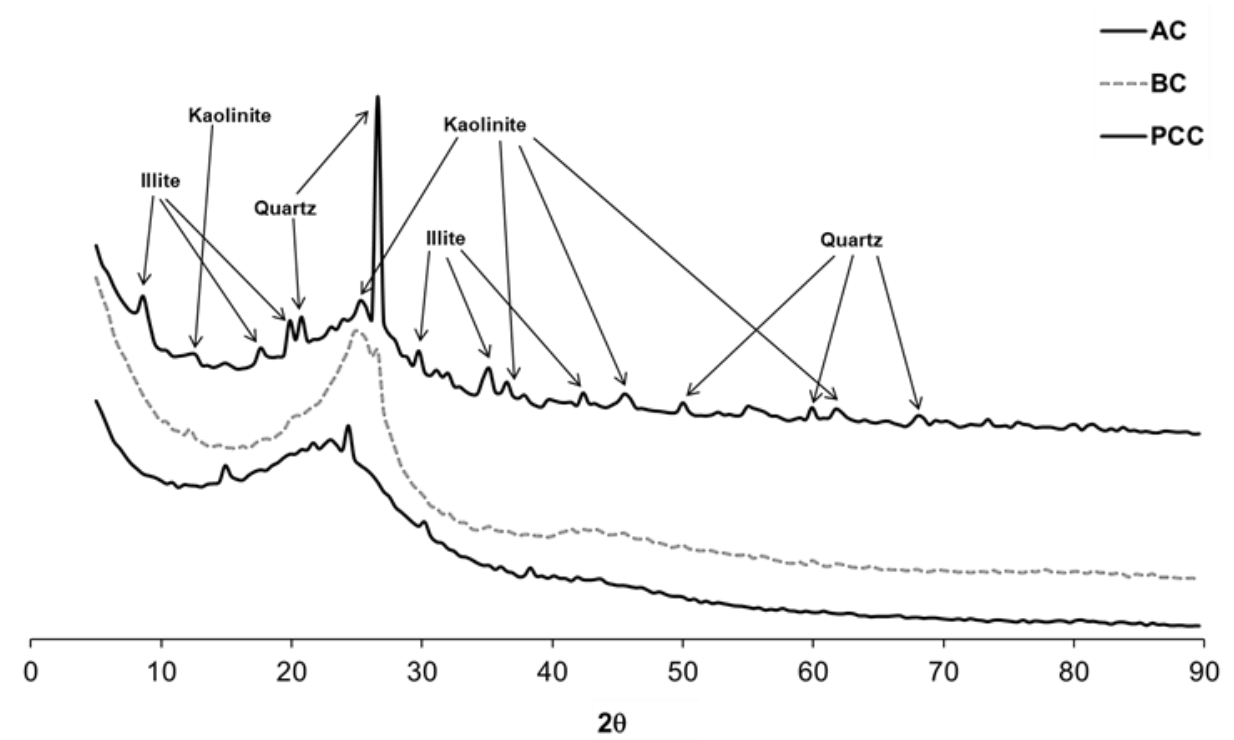

Figure 5. X-ray diffraction spectra of the carbon fuels tested.

Thermogravimetric analysis. A thermogravimetric analysis was carried out in the temperature interval of $25-1000{ }^{\circ} \mathrm{C}$ in order to gain insight into the reactivity of carbon fuels (Fig. 6). As can be seen the weight loss due to the increase of temperature in an inert atmosphere (Fig. 6a) is in accordance with the volatile matter content from the proximate analysis shown in Table 1, following the order: $\mathrm{PCC}>\mathrm{BC}>\mathrm{AC}$. The PCC sample undergoes the highest weight loss due to the deliberation of weakly bonded groups, especially between $400-800{ }^{\circ} \mathrm{C}$. This bond rapture is expected to create more reactive sites available to participate in other reactions occurring in the media. Figure $6 \mathrm{~b}$ shows the weight loss profiles with the increase of temperature in a $\mathrm{CO}_{2}$ atmosphere, where besides the effect of temperature on volatiles evolution, the carbon reaction with $\mathrm{CO}_{2}$ toward $\mathrm{CO}$ formation, through the reverse Boudouard reaction, is also carried out. The behavior of the AC sample is very similar either under $\mathrm{CO}_{2}$ or $\mathrm{N}_{2}$ flow, indicating its low reactivity. However, the weight loss difference of $\mathrm{BC}$ is clearly higher under $\mathrm{CO}_{2}$ flow. The pine charcoal (PCC) has been almost completely eliminated at $900{ }^{\circ} \mathrm{C}$, indicating its superiority in terms of reactivity compared to the other examined carbon samples. 

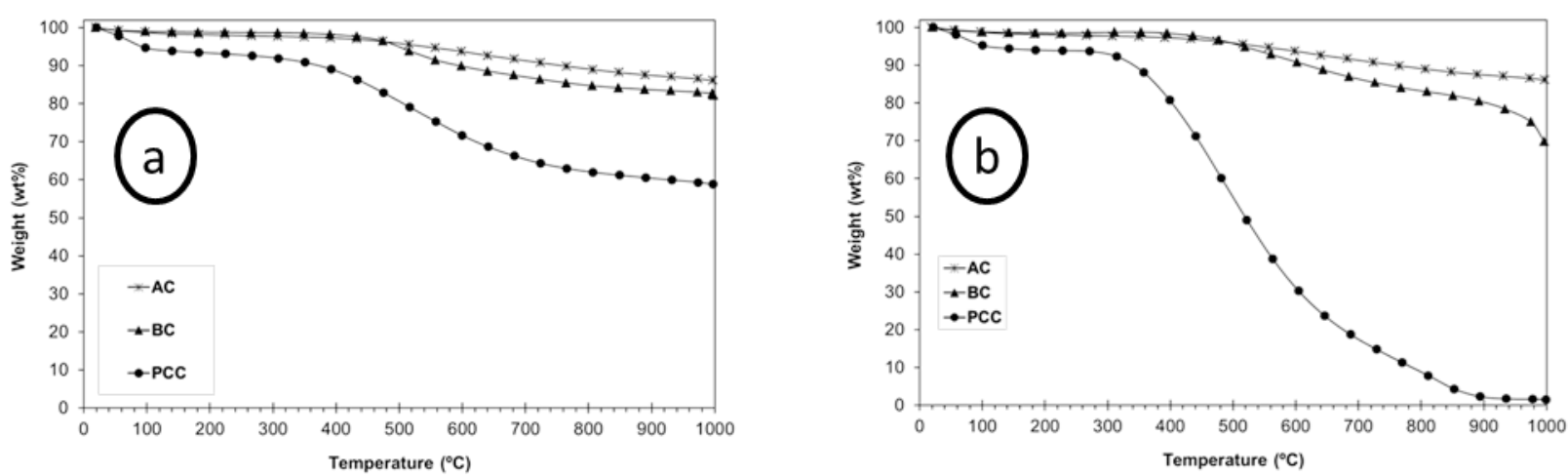

Figure 6. TGA of the carbon fuels: a) in inert $\left(\mathrm{N}_{2}\right)$ and b) in reactive $\left(\mathrm{CO}_{2}\right)$ atmospheres.

\subsection{DCFC performance}

Figure 7 depicts the impact of carbon type on DCFC performance, in terms of cell voltage, developed current and power output at 700, 750 and $800{ }^{\circ} \mathrm{C}$ under $\mathrm{CO}_{2}$ flow in the absence (empty symbols) and presence (solid symbols) of $20 \mathrm{wt} . \% \mathrm{Co} / \mathrm{CeO}_{2}$ in carbon feedstock. In catalyst-free experiments, the best performance is obtained by the PCC sample which exhibits a maximum power density of $2.3,7.0$, and $12.0 \mathrm{~mW} / \mathrm{cm}^{2}$ at 700,750 and $800{ }^{\circ} \mathrm{C}$, implying that biomass consists a promising feedstock in DCFC applications. Under the same conditions much lower power values are obtained with the $\mathrm{AC}$ and $\mathrm{BC}$, with the following order in terms of maximum power density $\mathrm{PCC}>\mathrm{BC}>\mathrm{AC}$, perfectly matching the results obtained during the thermo-gravimetric analysis of the different carbonaceous fuels under $\mathrm{CO}_{2}$ atmosphere (Fig. 6b). When the catalyst, 20 wt.\% $\mathrm{Co} / \mathrm{CeO}_{2}$, is ad-mixed with the carbon feedstock, the DCFC performance is promoted in all cases, with the enhancement being more pronounced at lower temperatures and for the least reactive fuels. However, again PCC shows the highest maximum power density values, equaled to 3.0, 8.0, and $13.5 \mathrm{~mW} / \mathrm{cm}^{2}$ at 700,750 and $800{ }^{\circ} \mathrm{C}$, respectively, following by $\mathrm{BC}$ and $\mathrm{AC}$ catalyst-incorporated samples.

It is evident that the physicochemical characteristics of carbon feedstock, such as the volatile matter, oxygen content, structure disorder and mineral impurities, play an important role in the electrochemical performance of the cell, as has been already demonstrated in [29]. In summary, the ash and sulfur contents follow the opposite trend with the maximum power, suggesting their inhibiting role in DCFC performance. In a similar manner, Vutetakis et al. [32] observed a sharp drop in the developed current at high overpotentials, ascribed to the passivation of electrodes by dissolved coal ashes. On the other hand, the volatile matter, porosity, structure disorder and reactivity of the samples with $\mathrm{CO}_{2}$ follow the same trend as the achieved power output, i.e., $\mathrm{PCC}>\mathrm{BC}>\mathrm{AC}$, implying their vital role in cell performance. Concerning the impact of sulphur on DCFC characteristics it has been demonstrated that a content of about 2-6 wt $\%$ sulphur in carbon fuels results in the degradation 
of cell performance due to sulphuric corrosion at the anode [12]. As can be seen from Table 2, only the AC sample has sulphur content in the above range, which can be further accounted for its inferior performance. As for the developed Open Circuit Voltage (OCV) concerns, it is observed that the OCV absolute values, although being lower than the theoretical expected OCV (ca. 1.0 V) for carbon oxidation, are increased with the operating temperature and when the catalyst is admixed in the carbon feedstock. Furthermore, a linear dependence of cell voltage on the developed current density is observed in all cases examined (dotted lines), whereas upon temperature increase and catalyst addition, depending on the reactivity of carbon samples, the cell voltage-current density slopes decrease, resulting in higher power outputs.
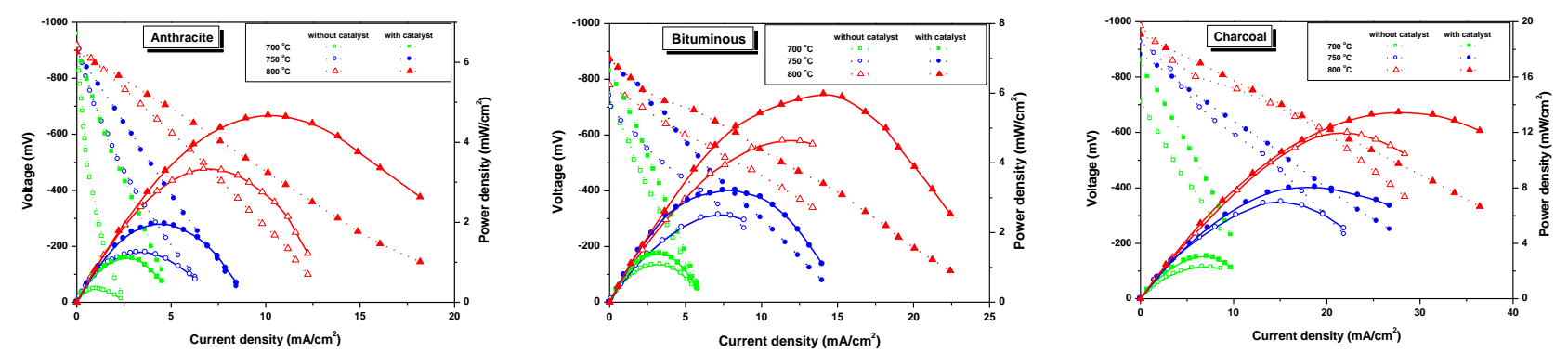

Figure 7. Impact of carbon type and catalyst infusion on the DCFC performance at 700, 750 and $800^{\circ} \mathrm{C}$. Carbon loading $=800 \mathrm{mg}$; catalyst loading $=400 \mathrm{mg} ; \mathrm{CO}_{2}$ flow $=30 \mathrm{~cm}^{3} / \mathrm{min}$.

The pronounced effect of catalyst addition to carbon feedstock on the DCFC performance is evident in the whole temperature range investigated, without, however, affecting the order of DCFC efficiency observed in the absence of catalyst $(\mathrm{PCC}>\mathrm{BC}>\mathrm{AC})$. The latter is ascribed to the in situ formation of gaseous $\mathrm{CO}$, through the catalyst-aided, reverse Boudouard reaction (reaction (5)). To clearly assess the impact of catalyst on DCFC characteristics, a new parameter, i.e. the maximum power enhancement ratio, $\rho_{\mathrm{P}_{\max }}$, is adopted, which is defined as:

$\rho_{\mathrm{P}_{\max }}=\mathrm{P}_{\max } / \mathrm{P}_{\max }^{\mathrm{o}}$

where $\mathrm{P}_{\max }$ and $\mathrm{P}_{\max }^{\mathrm{o}}$ are the maximum power outputs in the presence and absence of catalyst, respectively. In a similar manner, the CO rate enhancement ratio is defined as:

$\rho_{\mathrm{CO}}=\mathrm{r}_{\mathrm{CO}} / \mathrm{r}_{\mathrm{CO}}^{\mathrm{o}}$

where $r_{\mathrm{CO}}$ and $\mathrm{r}_{\mathrm{CO}}^{\mathrm{o}}$ are the $\mathrm{CO}$ formation rates at open circuit conditions in the presence and absence of catalyst, respectively.

The beneficial effect of catalyst is clearly revealed by the results presented in Table 3. At $750{ }^{\circ} \mathrm{C}$ $\rho_{\mathrm{P}_{\max }}$ values as high as 1.56, 1.28 and 1.15 are obtained for the AC, BC and PCC samples, respectively. Therefore, catalyst incorporation into carbon feedstock always results in a better DCFC per- 
formance $\left(\rho_{\mathrm{P}_{\max }}>1\right)$ independent of the carbon type and temperature employed. Interestingly, the observed trend in $\rho_{\mathrm{CO}}$ values is perfectly matching with the trend in $\rho_{\mathrm{P}_{\max }}$, once again demonstrating the key role of in situ formed CO on DCFC performance.

It is worth mentioning that in the case of the charcoal sample, the catalyst-induced increase in the CO formation rate $\left(\rho_{\mathrm{CO}}\right)$ is not accompanied by a similar increase in $\mathrm{P}_{\max }$ at high temperatures (Table 3). This can be possibly ascribed to the already high, un-catalyzed, $\mathrm{CO}$ formation rate over the pine charcoal and the limited conductivity of the employed cell due to the high ohmic resistances attributed to the thickness of the employed membrane and the poor adherence of the electrodes on the YSZ surface. The latter notably hampers the transfer of oxygen anions through the solid electrolyte and consequently the electro-oxidation of surplus $\mathrm{CO}$ formed in the presence of catalyst. This is in agreement with the development of lower currents $\left(\sim 34 \mathrm{~mA} / \mathrm{cm}^{2}\right)$ instead of theoretical values of $\sim 200 \mathrm{~mA} / \mathrm{cm}^{2}$, expected in the case of CO complete electro-oxidation over the charcoal sample. For example, Kulkarni et al. [36] employed 2 wt.\% Ni-infiltrated Yttria doped Ceria (20 mol\% YDC) and Gadolinia doped Ceria (40 mol\% GDC) as anodes in DCFC utilizing YSZ as electrolyte (thickness $=0.45 \mathrm{~mm}$ ) and activated coconut charcoal as feedstock. The optimum performance was observed for YDC anodes, which offered a maximum power density of ca. $40 \mathrm{~mW} / \mathrm{cm}^{2}$ at $800^{\circ} \mathrm{C}$, when 40 vol.\% $\mathrm{CO}_{2} / \mathrm{N}_{2}$ was employed as purging gas. This limitation could be bypassed by employing thinner electrolyte or electrode supported cells, which would allow the development of higher currents $[37,38]$.

Table 3. Impact of carbon type and catalyst on DCFC parameters at $700-800^{\circ} \mathrm{C}$ under $\mathrm{CO}_{2}$ flow.

\begin{tabular}{|c|c|c|c|c|c|c|c|}
\hline \multirow[t]{2}{*}{ Temperature } & \multirow[t]{2}{*}{ Feedstock } & \multicolumn{2}{|c|}{ Without Catalyst } & \multicolumn{2}{|c|}{ With Catalyst } & \multirow[t]{2}{*}{$\rho_{\mathrm{CO}}$} & \multirow{2}{*}{$\boldsymbol{\rho}_{\mathbf{P}_{\text {max }}}$} \\
\hline & & $\begin{array}{c}\mathbf{P}_{\max } \\
\left(\mathbf{m W} / \mathbf{c m}^{2}\right)\end{array}$ & $\begin{array}{c}\text { CO at } \mathrm{OC}^{*} \\
(\mu \mathrm{mol} / \mathrm{s})\end{array}$ & $\begin{array}{c}\mathbf{P}_{\max } \\
\left(\mathbf{m W} / \mathbf{c m}^{2}\right)\end{array}$ & $\begin{array}{c}\text { CO at OC* } \\
(\mu \mathrm{mol} / \mathrm{s})\end{array}$ & & \\
\hline \multirow[t]{3}{*}{$700^{\circ} \mathrm{C}$} & $\mathbf{A C}$ & 0.34 & 0.81 & 1.11 & 1.21 & 1.49 & 3.26 \\
\hline & BC & 1.09 & 1.09 & 1.40 & 1.42 & 1.30 & 1.28 \\
\hline & PCC & 2.31 & 2.15 & 3.06 & 2.69 & 1.25 & 1.32 \\
\hline \multirow[t]{3}{*}{$750{ }^{\circ} \mathrm{C}$} & $\mathbf{A C}$ & 1.25 & 1.11 & 1.96 & 1.67 & 1.50 & 1.57 \\
\hline & BC & 2.51 & 1.23 & 3.22 & 1.59 & 1.29 & 1.28 \\
\hline & PCC & 7.00 & 2.40 & 8.07 & 3.00 & 1.25 & 1.15 \\
\hline \multirow[t]{3}{*}{$800^{\circ} \mathrm{C}$} & $\mathrm{AC}$ & 3.35 & 1.30 & 4.68 & 1.95 & 1.50 & 1.40 \\
\hline & BC & 4.65 & 1.44 & 6.00 & 1.88 & 1.31 & 1.29 \\
\hline & PCC & 12.00 & 2.89 & 13.48 & 3.62 & 1.25 & 1.12 \\
\hline
\end{tabular}

*At Open Circuit (OC) conditions

The results depicted in Fig. 7 and Table 3 clearly reveal the strong correlation between the maximum power density and the $\mathrm{CO}$ formation rate; the maximum power coincides with the $\mathrm{CO}$ production rate, indicating the primary role of the latter in DCFC performance. These findings can be interpreted on the basis of the reverse Boudouard reaction $\left(\mathrm{C}+\mathrm{CO}_{2} \rightarrow 2 \mathrm{CO}\right)$ extent over the different 
fuels, which is further promoted by the incorporation of a catalyst in the carbon feedstock. The in situ formed $\mathrm{CO}$, which presents better diffusion characteristics and faster electro-oxidation kinetics compared to solid carbon, is then subsequently electro-oxidized at the anode TPB for power generation. The proposed scheme of a DCFC integrated with an internal catalytic gasification process is schematically illustrated in Figure 8.

In view of the above aspects, Tang and Liu [25] and Nakagawa and Ishida [39], reported that the formation of gaseous $\mathrm{CO}$ through the reverse Boudouard reaction is the key step in DCFC operation. Along the same lines, the increased performance of a Ni/YSZ anode-supported solid oxide fuel cell with coke fuels and $\mathrm{CO}_{2}$ as carrier gas was attributed to the increased extent of the electrochemical oxidation of produced CO through reaction (5) [27]. The key role of gaseous products electrooxidation has been comprehensively studied by Li et al. [40] who explored the electrochemical behavior of both a detached and in contact anode with carbon fuel. They demonstrated that the anode reaction mechanism is the same in both configurations without in any sense involving the direct electro-oxidation of carbon at the interphase between fuel and anode [40]. Moreover, it has been reported that $\mathrm{Sn}$ addition to carbon black in a Ni/YSZ-anode SOFC, provided a 4-fold enhancement of power density compared to $\mathrm{Sn}$-free fuel, which was attributed to the facilitation of carbon oxidation kinetics [41].

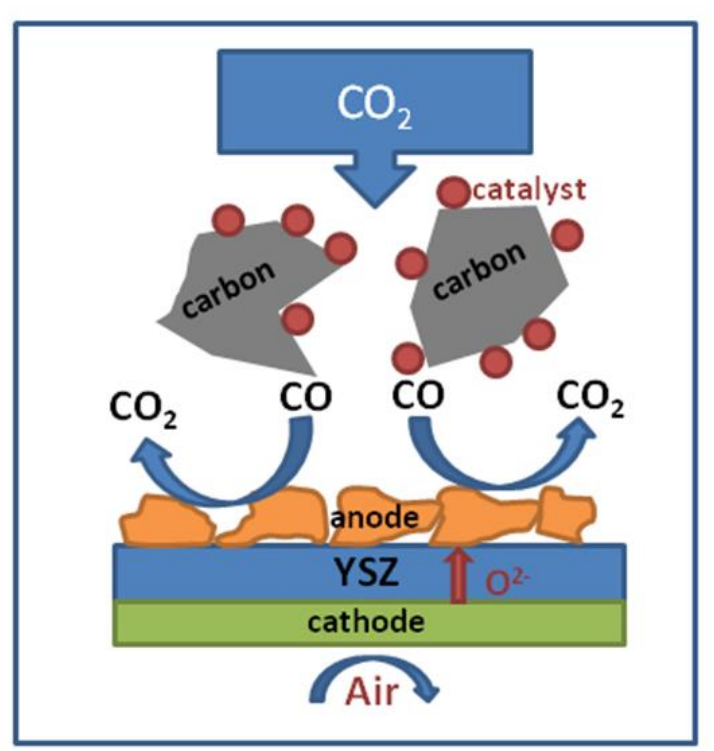

Figure 8. Schematic illustration of a DCFC merged with a catalyst-aided gasification process.

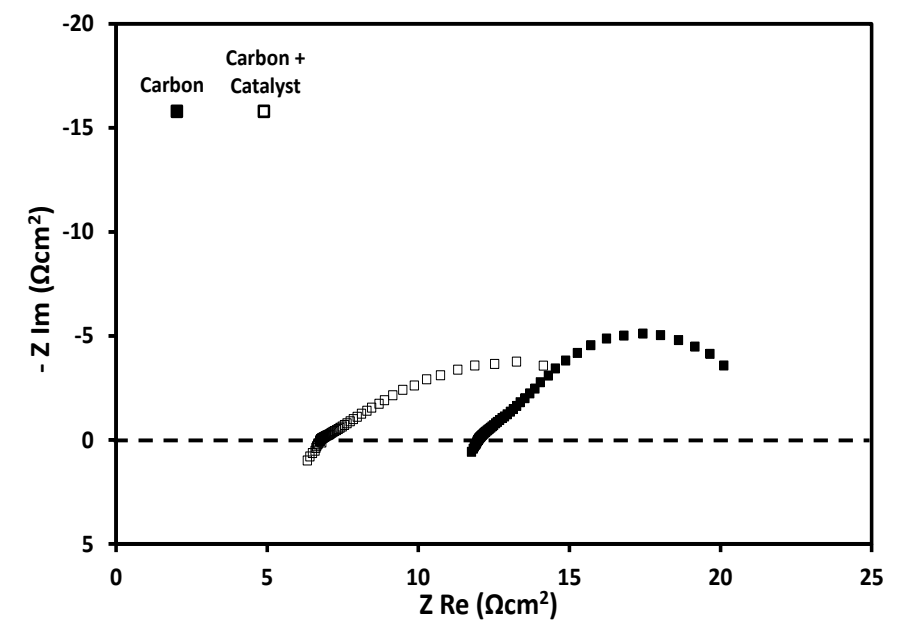

Figure 9. AC impedance spectra at $750^{\circ} \mathrm{C}$ in the absence and presence of $\mathrm{Co} / \mathrm{CeO}_{2}$ in Bituminous coal feedstock. Carbon $=800 \mathrm{mg}$; catalyst $=400 \mathrm{mg}$; $\mathrm{CO}_{2}$ flow $=30 \mathrm{~cm}^{3} / \mathrm{min}$.

To further clarify the impact of catalyst infusion into carbon feedstock on DCFC electrochemical 
characteristics, AC impedance studies were also carried out. Fig. 9 depicts the AC impedance spectra at $750{ }^{\circ} \mathrm{C}$ of $\mathrm{BC}+\mathrm{CO}_{2}\left|\mathrm{Cu}-\mathrm{CeO}_{2} / \mathrm{YSZ} / \mathrm{Ag}\right|$ air cell in the absence and upon the addition of 20 wt.\% $\mathrm{Co} / \mathrm{CeO}_{2}$ in the bituminous coal feedstock using $\mathrm{CO}_{2}$ as gasifying agent. Their feature is comprised of a small high frequency (HF) arc, with a double layer pseudo-capacitance value in the range of $10^{-}$

${ }^{4}-10^{-5} \mathrm{~F} / \mathrm{cm}^{2}$, associated mainly to the gasification process, overlapped with a larger low frequency (LF) arc corresponding to mass transfer limitations. By comparing the two AC impedance spectra, it can be obviously identified the lower ohmic resistance achieved upon catalyst incorporation (7 $\left.\Omega . \mathrm{cm}^{2}\right)$ compared to the catalyst-free experiment $\left(12 \Omega . \mathrm{cm}^{2}\right)$, which can be attributed to the gradual reduction of anode electrode by the surplus $\mathrm{CO}$ generated via the catalyst-aided reverse Boudouard reaction, as also observed in [42]. Regarding, the electrode resistance, it seems that the catalyst infusion into the $\mathrm{BC}$ feedstock improves the HF resistance, attributed to the $\mathrm{CO}_{2}$ coal gasification process without however affecting substantially the mass transfer LF arc, which prevails the AC impedance spectra feature. The corresponding values for the area specific resistance, ASR, are equal to 21 and $17 \Omega . \mathrm{cm}^{2}$ for the experiments performed in the absence and presence of catalyst in the Bituminous coal feedstock, respectively, reflecting the improvements observed in DCFC performance upon catalyst usage.

\section{CONCLUSIONS}

The combined impact of carbon type and internal, catalyst-aided, carbon gasification process on the performance of a Direct Carbon Fuel Cell was explored, by employing anthracite (AC), bituminous (BC) and pine charcoal (PCC) as feedstock and $\mathrm{Co} / \mathrm{CeO}_{2}$ catalyst as carbon additive. The following order, in terms of maximum power, is recorded in catalyst absence: $\mathrm{PCC}>\mathrm{BC}>\mathrm{AC}$, perfectly matching with their reactivity under $\mathrm{CO}_{2}$ atmosphere. The optimum behaviour was obtained for pine charcoal $\left(\sim 12 \mathrm{~mW} / \mathrm{cm}^{2}\right)$, demonstrating the potential of biomass as fuel in DCFCs. Incorporation of $\mathrm{Co} / \mathrm{CeO}_{2}$ catalyst into carbon feedstock results in an increase of cell power up to $225 \%$ depending on carbon type and temperature. The enhanced performance obtained by internally ad-mixing carbon fuel with $\mathrm{Co} / \mathrm{CeO}_{2}$ catalyst is ascribed to the pronounced impact of catalyst on the in situ carbon gasification toward $\mathrm{CO}$ formation, which presents better diffusion and faster electro-oxidation kinetics compared to solid carbon, thus enhancing substantially the achieved power densities. A direct correlation between the DCFC performance and the $\mathrm{CO}$ formation rate was revealed, further interpreted on the basis of AC impedance studies. The present results demonstrate the potential for the simultaneous utilization of low-value carbonaceous solid fuels and gaseous $\mathrm{CO}_{2}$ waste gas streams, by means of a catalyst-aided DCFC process. 


\section{Acknowledgments}

The authors would like to acknowledge financial support from the ERANET-MED (Call identifier RQ2-2016) project "Direct Conversion of Biomass to Electricity in MED area via an Internal Catalytic Gasification Solid Oxide Fuel Cell”, which is co-funded by the following Euro-Mediterranean countries: Algeria, Cyprus, Egypt, France, Germany, Greece, Italy, Jordan, Lebanon, Malta, Morocco, Spain, Tunisia, Turkey. (ERANETMED2-72-246 DB-SOFC).

\section{References}

[1] International Energy Outlook 2011, U.S. Energy Information Administration, http://www.eia.gov/forecasts/ieo/pdf/0484(2011).pdf

[2] Giddey S, Badwal SPS, Kulkarni A, Munnings C. A comprehensive review of direct carbon fuel cell technology. Prog Energy Combust Sci 2012;38:360-99.

[3] Cao T., Huang K. Shi Y., Caia N. Recent advances in high-temperature carbon-air fuel cells. Energy Environ. Sci., 2017;10:460-490.

[4] Gür TM. Critical review of carbon conversion in "Carbon Fuel Cells". Chem Rev 2013;113:6179-6206.

[5] Li X, Zhu Z, Marco RD, Bradley J, Dicks A. Modification of coal as a fuel for the direct carbon fuel cell. J Phys Chem A 2010;114:3855-62.

[6] Nürnberger S, Bußar R, Desclaux P, Franke B, Rzepka M, Stimming U. Direct carbon conversion is a SOFC-system with a non-porous anode. Energy Environ Sci 2010;3:150-3.

[7] Jiang C., Ma J., Corre G., Jain S.L., Irvine J.T.S. Challenges in developing direct carbon fuel cells. Chem. Soc. Rev. 2017;46:2889-2912.

[8] Zecevic S, Patton EM, Parhami P, Carbon-air fuel cell without a reforming process. Carbon 2004;42: 1983-93.

[9] Zhang J, Zhong Z, Zhao J, Yang M, Li W. Study on the preparation of activated carbon for direct carbon fuel cell with oak sawdust. The Can J Chem Eng 2012;90:762-8.

[10]Lee CG, Ahn KS, Lim HC, Oh JM. Effect of carbon monoxide addition to the anode of a molten carbonate fuel cell. J Power Sources 2004;125:166-71.

[11]Hackett GA, Zondlo JW, Svensson R. Evaluation of carbon materials for use in a direct carbon fuel cell. J Power Sources 2007;168:111-8.

[12] Cherepy NJ, Krueger R, Fiet KJ, Jankowski AF, Cooper JF., Direct conversion of carbon fuels in a molten carbonate fuel cell. J Electrochem Soc 2005;152: A80-7.

[13]Dicks AL. The role of carbon in fuel cells. J Power Sources 2006;156:128-41.

[14]Cao D, Sun Y, Wang G. Direct carbon fuel cell: Fundamentals and recent developments. J Power Sources 2007;167:250-7. 
[15] Nabae Y, Pointon KD, Irvine JTS. Ni/C Slurries based on molten carbonates as a fuel for hybrid direct carbon fuel cell. J Electrochem Soc 2009;156: B716-20.

[16] Gür TM, Homel M, Virkar AV. High performance solid oxide fuel cell operating on dry gasified coal. J Power Sources 2010;195:1085-90.

[17]Li C, Shi Y, Cai N. Performance improvement of direct carbon fuel cell by introducing catalytic gasification process. J Power Sources 2010;195:4660-6.

[18] Wu Y, Su C, Zhang C, Ran R, Shao Z. A new carbon fuel cell with high power output by integrating with in situ catalytic reverse Boudouard reaction. Electrochem Commun 2009;11:12658.

[19] Wang CQ, Liu J, Zeng J, Yin JL, Wang GL, Cao DX. Significant improvement of electrooxidation performance of carbon in molten carbonates by the introduction of transition metal oxides. J Power Sources 2013;233:244-51.

[20]Cao D, Wang G, Wang C, Wang J, Lu T. Enhancement of electrooxidation activity of activated carbon for direct carbon fuel cell. Int J Hydrogen Energy 2010;35:1778-82.

[21]Li X, Zhu Z, Chen J, De Marco R, Dicks A, Bradley J, Lu G. Surface modification of carbon fuels for direct carbon fuel cells. J Power Sources 2009;186:1-9.

[22]Zhang J, Zhong Z, Shen D, Zhao J, Zhang H, Yang M, Li W. Preparation of Bamboo-based activated carbon and its application in direct carbon fuel cells. Energy Fuels 2011;25:2187-93.

[23] Paraknowitsch JP, Thomas A, Antonietti M. Carbon colloids prepared by hydrothermal carbonization as efficient fuel for indirect carbon fuel cells. Chem Mater 2009;21:1170-2.

[24]Li X, Zhu Z, Marco RD, Bradley J, Dicks A. Carbon Nanofibers synthesized by catalytic decomposition of methane and their electrochemical performance in a direct carbon fuel cell. Energy Fuels 2009;23:3721-31.

[25]Tang Y, Liu J. Effect of anode and Boudouard reaction catalysts on the performance of direct carbon solid oxide fuel cells. Int J Hydrogen Energy 2010;35:11188-93.

[26]Deleebeeck L., Ippolito D., Kammer Hansen K. Enhancing hybrid direct carbon fuel cell anode performance using Ag2O. Electrochimica Acta 2015;152:222-239.

[27] Chien AC, Chuang SSC. Effect of gas flow rates and Boudouard reactions on the performance of Ni/YSZ anode supported solid oxide fuel cells with solid carbon fuels. J Power Sources 2011;196:4719-23.

[28]Chien AC, Siengchum T, Chuang SSC. Dielectric and semiconductor materials, devices, and processing. ECS Trans 2011;33:75-85.

[29] Kaklidis N., Kyriakou V., Garagounis I., Arenillas A., Menéndez J.A., Marnellos G.E., Konsolakis M. Effect of carbon type on the performance of a direct or hybrid carbon solid oxide fuel cell. RSC Adv. 2014; 4:18792 - 18800. 
[30]Li X, Zhu Z, De Marco R, Bradley J, Dicks A. Evaluation of raw coals as fuels for direct carbon fuel cells. J Power Sources 2010;195:4051-58.

[31] Xu X, Zhou W, Liang F, Zhu Z. A Comparative study of different carbon fuels in an electrolyte-supported hybrid direct carbon fuel cell. Appl Energy 2013;108:402-9.

[32] Vutetakis DG, Skidmore DR, Byker HJ. Electrochemical oxidation of molten carbonate-coal slurries. J Electrochem Soc 1987;134:3027-35.

[33] Dudek M, Tomczyk P, Socha R, Skrzypkiewicz M, Jewulski J. Biomass fuels for direct carbon fuel cell with solid oxide electrolyte. Int J Electrochem Sci 2013;8:3229-53.

[34] Ahn SY, Eom SY, Rhie YH, Sung YM, Moon CE, Choi GM, Kim DJ. Utilization of wood biomass char in a direct carbon fuel cell (DCFC) System. Appl Energy 2013;105:207.

[35] Konsolakis M., Kaklidis N., Marnellos G.E., Zaharaki D., Komnitsas K. Assessment of biochar as feedstock in a direct carbon solid oxide fuel cell. RSC Adv. 2015;5:73399 - 73409.

[36] Kulkarni A., Giddey S., Badwal SPS. Yttria doped ceria anode for carbon-fuelled solid oxide fuel cell. J. Solid State Electrochem. 2015;19:325-335.

[37]Deleebeeck L., Gil V., Ippolito D., Campana R., Kammer Hansen K., Holtappels P. Direct coal oxidation in modified solid oxide fuel cells. Journal of The Electrochemical Society 2017;164(4):F333-F337.

[38] Nabae Y., Pointon K.D., Irvine J.T.S. Electrochemical oxidation of solid carbon in hybrid DCFC with solid oxide and molten carbonate binary electrolyte. Energy Environ. Sci. 2008;1:148-155.

[39] Nakagawa N, Ishida M. Performance of an internal direct-oxidation carbon fuel cell and its evaluation by graphic exergy analysis. Ind Eng Chem Res 1988;27:1181-5.

[40]Li C, Shi Y, Cai N. Effect of contact type between anode and carbonaceous fuels on direct carbon fuel cell reaction characteristics. J Power Sources 2011;196:4588-93.

[41]Ju HK, Uhm S, Kim JW, Song R-H, Choi H, Lee S-H, Lee J. Enhanced anode interface for electrochemical oxidation of solid fuel in direct carbon fuel cells: The role of liquid $\mathrm{Sn}$ in mixed state. J Power Sources 2012;198:36-41.

[42] Kaklidis N., Kyriakou V., Marnellos G.E., Strandbakke R., Arenillas A., Menendez J.A., Konsolakis M. Effect of fuel thermal pretreatment on the electrochemical performance of a direct lignite coal fuel cell. Sol. St. Ionics 2017;306:31-37. 